\title{
Methodological Aspects of Implementation of the Safety System in the Activity of Hotel and Catering Industry Enterprises
}

\author{
Viktoria Prokhorova $^{1}$, Oksana Davydova $^{2^{*}}$, Valentina Protsenko ${ }^{3}$ \\ ${ }^{1}$ Ukrainian Engineering Pedagogics Academy \\ ${ }^{2}$ Kharkiv State University of Food Technology and Trade \\ ${ }^{3}$ Department of the higher qualification certification and licensing of the Ministry of Education and Science \\ *Corresponding author E-mail: davydova_oks@ukr.net
}

\begin{abstract}
The essence of the HACCP system is revealed. The urgency of the development and implementation of the HACCP system in the hotel and catering business enterprises is proved either. The conceptual aspects of the HACCP methodology are presented that allows to maintain the focus on the safety and quality of the products and services of the hotel and catering industry as the highest priority. The successive stages of the HACCP system implementation in the hotel and catering business have been developed. The checklist for analyzing the risks of the process of reception and accommodation of the consumers at the hotel is presented either. It has been proved that the development and implementation of the HACCP system will provide the hotel and catering industry with the competitive advantages.
\end{abstract}

Keywords: Consumer; critical control point; hotel and catering economy; products; quality; risk; security; services; HACCP system

\section{Introduction}

The exacerbation of the competitive struggle in a globalized world has naturally highlighted the quality, security and competitiveness issues at the macro and microeconomic levels. The quality and safety of the products and services has become a universal requirement presented by an open economy on any economic entity. Ukraine has a large extensive, natural, industrial and scientific potential, but the determinants of its competitive advantages are still underdeveloped, that determines the insufficiently high quality and competitiveness of the domestic products and services. Consequently, the foreign companies hold strong positions in the Ukrainian market of products and services. Therefore, the possibility of a stable economic growth and the change of Ukraine's position at the world market will depend on how efficiently the state and business will address the issue of quality, safety and competitiveness of products and services.

The fundamental premise of all hospitality companies activity is the services provision of that are safe for health and life for the consumers, as well as the defense of their property and environmental protection.

The safety and quality of the services provided by the establishments of the hotel and catering industry is a precondition for the stable functioning of the industry, as well as the pledge of trust and commitment of the consumers.

Uncontrolled use of the chemical raw materials, artificial substitutes, contamination of the environment, the use of unauthorized additives, microbiological hazards and other abuses throughout the supply chain from the original supplier to the consumer, can lead to the risk of services.

All this testifies about the need to develop a system that will ensure the quality and safety of the hotel and catering services. The system should provide an analysis of the hazards (risks) that may occur during the provision of services and prevent their occurrence.

\section{Main Body}

The world-renowned system that allows you to receive safe products is the HACCP system. It is used in the world's major economies as a risk management system in the food establishments. This is a system referred at the elimination of the health risks related to food intake and the reduction of the number of infectious diseases and food poisoning [1].

\subsection{General Provisions of the HACCP System}

HACCP is abbreviated to the name of Hazard Analysis and Critical Control Points, which is a synonymous with a food safety management.

The HACCP system was first developed as a microbiological safety system in the early stages (in the 60th years) of the implementation of the American program of human flight into the space, because such a system was vital for the safety of food products intended for the astronauts.

The main principles of the HACCP concept were not new ones, but their implementation indicated the shift of priorities from testing the final product to precautionary control at the critical points of the technological process.

The HACCP system is responsible for defining of the critical aspects of the safe food products manufacture for the producers. It provides food manufacturers with the opportunity to improve the effectiveness of controls by introducing an ordered, systematic approach to the food safety procedures. The concept also gives to the inspectors in this industry the opportunity to get a more com- 
plete and accurate picture of the effectiveness of controlling the process over a longer period of time.

The initial system was developed by Pillsbury, along with the National Aeronautics and Space Administration and the US Army Laboratories. It was based on the Danish standard DS 3027 E, then the European standard was developed, and today there is an international DS / EN ISO 9000 standard.

The HACCP system and guidelines for its application are developed by the Committee in Food Hygiene under the Codex Alimentarius Commission, the Joint Food Standards Program of the Food and Agriculture Organization (EAW) under the United Nations and the World Health Organization and endorsed by the Expert Committee Commission in Food at the United Nations "Codex Alimentarius" (SAS) in 1993.

The latest edition of the EU Regulation No. 852/2004 on the food hygiene indicates the need to use HACCP system to ensure food safety. Thus, HACCP system as a basis for the production of the safe food for consumption has received a world recognition.

Currently, the introduction and application of HACCP system in the food industry in the countries of the European Union, the USA, Canada, and its certification are mandatory.

The combination of HACCP with traditional inspections and quality control measures leads to the establishment of a quality assurance system with preventive action in the enterprise. Establishments which use HACCP system are able to guarantee greater confidence in the consumer safety and food quality control authorities.

The main task of implementing the HACCP system is to manage product safety and prevent food poisoning.

This methodology has approved itself as an effective tool for preventing the occurrence of food product mismatches in the process, as well as identifying and eliminating problems before inappropriate production become a source of poisoning or deterioration of the consumers health.

The HACCP system is a verified system that provides confidence in a successful product safety management. The HACCP system is fully recognized and used internationally in the food industry, trade, insurance, and legislation. Recognition of this system in the economically developed countries of the world is due to the fact that its application guarantees the production of the safe products, provides a reduction in production costs, gives to the consumer a confidence in the safety of production.

\subsection{Strategic Measures for the Implementation of the HACCP System in the Hotel and Catering Enterprises}

It should be noted that the concept of HACCP was originally created to ensure the quality of the food products, but this application of the HACCP system is not limited. There is some experience in the integrated implementation of the HACCP system in the manufacture of the medical products and the provision of the medical services, catering services, etc. [1-3].

A comprehensive analysis of HACCP system functioning made it possible to predict the possibility of its application in the hotel and catering business enterprises.

For the first time we developed organizational measures for the implementation of the HACCP system in the sphere of hotel and catering business.

The strategic objective of HACCP security system in the hotel and catering business is to study each step, the stage of the service delivery process, identify risks, hazards, and implement effective monitoring methods and monitoring procedures.

HACCP system has an anticipating (preventive) character regarding to the services safety.

Conceptually, HACCP system provides the systematic identification, evaluation and management of hazardous factors that significantly affect the security of services.

The introduction of HACCP system in hotel and catering facilities involves the process of the parameters control of the technological process of providing services, the evaluation of information and materials used for the provision of services, and also implements a strategy of guaranteeing their security and is based on three principles:

1. Legislative requirements for the provision of hotel and catering services.

2. A profound scientific approach to the decision making.

3. Control over compliance with legislative requirements.

HACCP is not a zero-risk system, but it prompts the minimization of the risk from potentially hazardous factors. Based on the modern science-based requirements, this system will provide a preventive approach and will enable effectively manage the safety of hotel and catering services.

\subsection{Development of Organizational Measures for the Development and Implementation of HACCP System in the Hotel and Catering Enterprises}

We will develop the consecutive stages of HACCP system implementation in the hotel at the technological stage of reception and arrangement of consumers.

1. Creation of a HACCP group and determination of the scope and objectives of the HACCP plan. Documentation and implementation of HACCP is a task of a group with experience and highly skilled knowledge about the full product life cycle, ranging from inputs, process supply to receiving services by the customers.

It is necessary to create a multidisciplinary group of HACCP for a high-quality and safe service of the hotel visitors which will consist of specialists of different specialties who will cover the entire scope of the HACCP plan:

- hotel director - a leader of the HACCP group;

- accountant;

- administrator;

- employees of the technical service;

- engineer for safety and occupational safety.

Before beginning of its work, the group will determine the volume of operations performed in the process of providing services in this institution and develop the purpose of the project. The goal of the project is to ensure the safety and quality of service for the hotel guests.

2. Description of the services. Provide a description of the services and contains the following information: service description; storage; characteristics of the final services; services provision; inner packaging; over pack; storage requirements; method of distribution; date of expiry; special marking; preparation for consumption, process of service.

The process of the services provision which is under the consideration consists of the steps that are performed in a certain sequence:

1. Greetings.

2. Checking of the order.

3. Registration of the record entry.

4. Data verification.

5. Number and tariff identification.

6. The establishment of the method of calculation.

7. The issuing of the room keys.

8. Customer escort to the room

9. Demonstration of the room.

10. Luggage delivery.

3. Identification of the services use as intended. Identifying the potential customers and the most vulnerable consumers. The description of the services use according to the purpose is carried out in keeping in the peculiarities of their provision. The description is based on the expected normal receipt of the services by the end consumer. Exceptionally, the vulnerable groups are estimated. There are five vulnerable groups of the population: senior citizens, infants, pregnant women, sick people, people with a weak immune system.

4. Designing of a process diagram. The process diagram covers the full scope of the HACCP plan from beginning to end, in other words, all technological stages. The process diagram (or process flow diagram of the service delivery process) provides an overview of the processes, covering all of their steps and the basis for further risk analysis. The developed process diagram helps to 
identify the potential sources of a danger, offer control tools and concentrate discussions and assessments by the HACCP team at certain points.

5. Check of the process diagram at the hotel. For the investigated services the checking of the process diagram is carried out at the reception desk. The HACCP team approves the compliance of the technological processes of the process diagram, during all stages and time of the activity, and, if it's necessary, make changes. Verification of the processes in real life is a mandatory requirement. 6. Conducting of a risk analysis according to the process diagram. Risk is a biological, chemical, economic or physical factor, their connection or the services state that can adversely affect on a human health or the degree of consumer satisfaction (high-risk). The HACCP team that was created at the hotel, lists all potential risks that are likely to occur at the each stage of the customer service process.

This is one of the key steps in the course of which creates a list of all risks that can be expected at the each stage, and then determine which of the potential risks are of a nature that should be eliminated or reduced to the acceptable levels for the customer service process at the hotel.

In the conducting of the risk analysis, the following factors should be considered:

- the probability of the risks occurrence and the value of their impact on health;

- qualitative and (or) quantitative assessments of the present risks; - survival or reproduction of the microorganisms present;

- occurrence or resistance to toxins, chemical or physical substances;

- conditions that lead to all of the above.

Then the team examines whether there are control measures and if so, how they can be applied to each of the risks.

Risk analysis consists of three parts:

1. Identification of risks.

2. Determining of the risks significance.

3. Determination of the preventive measures.

All potential risks that are related to the use of the HACCP system are identified, documented and evaluated, depending on their significance and the probability of occurrence.

After identifying of the risks for each significant one, measures are set up to manage them. They must alert or eliminate the risk, or reduce it to an acceptable level. If this is not possible, then the service or process needs to be modified. The analysis of the potential risks is presented in the table.

7. Definition of the critical control points - CCP is a stage (operation) of a process where control is possible and which is essential for the prevention or elimination of a risk that threatens the security of the service or reduce it to the acceptable level. For each significant risk which is identified during the risk analysis, there must be one or more CRTs where this risk is controlled. Only points that can control risks are significant for the security of services and can be considered as a CCP.

Possible probability of the control stages existence, which are not directly related to the control of safety. In this case, the PTV is a point that requires attention or control points (CPs) - points, stages that control the quality of services, or implement additional measures for managing of the service safety.

If there is a difficulty in determining the difference between $\mathrm{CCP}$ and $\mathrm{CP}$, then one should ask a simple question: "If there is no control, will this mean that there is a risk to the consumer's health?"

The factors that can significantly affect on the quality of products and services of the hotel and catering industry and be the potential risks include: hazardous raw materials, non-compliance with the technological process, non-delivery of raw materials, noncompliance with the prescription composition, temperature, shelf life, sanitary norms and rules of production and process of service, non-compliance with sanitary and hygienic requirements of personnel, poor sanitary procedures, etc.
The characteristics of the hotel and catering services, which must be paid a special attention in order to ensure their quality and safety, include:

- power, capabilities, number of a staff and quantity of materials;

- waiting time, time of delivery and time of the technological cycle of the service;

- hygiene, safety, reliability and guarantees;

- responsiveness, sociability and courtesy of the staff, comfort and aesthetics of the interior, competence, reliability, accuracy, completeness, compliance with the current level, reliability and effectiveness of contacts, etc.

All significant risks should be managed through the management of measures which are set out in one or more CCPs. For all significant risks, documentation should be available that confirms that the CCP is installed using the system method. For each CCP, it is necessary to select the relevant characteristics which come under the monitoring and clearly indicate that the control measures contribute to the desired outcome.

8. Establishing of maximum permissible levels for each CCP. For selected characteristics that lie under the monitoring, maximum permissible levels should be set for each CCP, as well as the operating margins that determine the difference between safe and dangerous products. The maximum permissible levels that are established should be applied for all CCP; be substantiated; verified, confirmed; measured.

Services will be safe undoubtedly if all CCPs are effectively managed within the specific maximum permissible levels which are established for them. In case of a process at the maximum permitted levels, corrective action is required to ensure the security of the services.

9. Establishing of the monitoring for each CCP. Loss of control in the CCP should reveal the monitoring procedure. It must be continuous, or its periodicity must be sufficient to guarantee the detection of possible deviations from the maximum permissible levels and operating limits, and thus the maintenance of control in the $\mathrm{CCP}$. The monitoring system with the necessary instructions includes:

- method and frequency of monitoring;

- personnel responsible for monitoring;

- personnel responsible for evaluating of the monitoring results; - documenting of the monitoring results.

Monitoring is carried out in order to know when the CCP is out of control, increasing the risk of providing a hazardous service; identify problems before their occurrence; specify the causes of problems; encourage to the verifying of the HACCP plan.

10. Setting of the corrective actions for possible deviations. It is necessary to establish characteristic documented corrective actions for each CCP that are used in cases where the monitoring of the result in the CCP indicates a loss of control. Two steps (parts) of corrective action must be taken:

1. Immediate action:

- adjustment of the process for return of control;

- disposal of spoiled services.

2. Precautionary measures:

- informing the person who is responsible for the corrective action; - registration of corrective actions.

The purpose of the precautionary action is to identify and rule out the cause of the problem. Pre-defined corrective actions are introduced into the HACCP plan.

11. Establishing of the verification procedures. Verification is the application of methods, procedures, tests and other assessment tools, in addition to monitoring, determine whether the HACCP plan is being implemented. The hotel and catering business must establish and maintain scheduling and periodic inspection procedures in order to determine whether the system is operating in accordance with HACCP plan.

Activities related to the verification of the HACCP consist of the following actions:

- validation of HACCP in order to convince all elements of

HACCP plan to be carried out;

- analysis of monitoring results; 
- product testing;

- conducting audits.

System verification is planned based on the status and importance of the activity and should be performed by the qualified personnel. The results of the verification should be documented.

12. Establishing of the procedures for documenting and keeping the records. HACCP requires the creation of a procedure for efficient record keeping (protocols) that log the HACCP system. HACCP procedures should be documented.

During the implementation of the HACCP system in order to obtain safe services as a result of the organization of the service, it is necessary:
- to control the services, conditions of their provision, organization of consumption, services must comply with the requirements of the relevant normative and technical documentation;

- the conditions of service during the provision of services must comply with the requirements of the current normative documentation on the level of noise, vibration, illumination, the state of the microclimate, architectural and planning and constructive decisions, indicators of electric, fire and explosion safety;

- in the process of direct customer service, the hotel requires direct control by the administrator or director;

- production and service personnel must be adequately trained and comply with sanitary and personal hygiene rules in services provision [4-5].

Table: A checklist a risk analysis

\begin{tabular}{|c|c|c|c|c|c|c|c|c|c|c|c|c|}
\hline \multicolumn{6}{|c|}{ Principle 1 (step 6) } & \multicolumn{7}{|c|}{ Principle 2 (step 7) } \\
\hline $\begin{array}{l}\text { Stage } \\
\text { Greet- } \\
\text { ing }\end{array}$ & Risk & Reason / Excuse & $\begin{array}{c}\text { Probability } \\
\text { (H) } \\
\text { (A) } \\
\text { (L) } \\
\end{array}$ & $\begin{array}{c}\text { Significance } \\
\text { (H) } \\
\text { (A) } \\
\text { (L) } \\
\end{array}$ & $\begin{array}{l}\text { Control/ } \\
\text { Warning } \\
\text { Events }\end{array}$ & Q 1 & Q 2 & Q3 & Q4 & $\begin{array}{l}\mathbf{Q} \\
\mathbf{5}\end{array}$ & $\begin{array}{c}\mathrm{CCP} / \\
\mathrm{CPC} / \\
\mathrm{CP}\end{array}$ & Reason for solving \\
\hline \multirow[b]{2}{*}{ 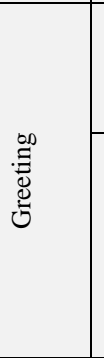 } & Biological & $\begin{array}{l}\text { Transfer of micro- } \\
\text { organisms from } \\
\text { infected staff }\end{array}$ & $\mathrm{N}$ & \begin{tabular}{c|}
$\mathrm{C}$ \\
\end{tabular} & $\begin{array}{l}\text { Checking of a the } \\
\text { staff health with a } \\
\text { formal inspection }\end{array}$ & Yes & Yes & Yes & - & - & $\mathbf{C C P}$ & $\begin{array}{l}\text { Monitoring of the } \\
\text { staff health, identi- } \\
\text { fying symptoms at } \\
\text { the early stages }\end{array}$ \\
\hline & Qualitative & $\begin{array}{l}\text { Problems with the } \\
\text { entrance to the } \\
\text { hotel (greasy } \\
\text { steps), badly } \\
\text { opened door }\end{array}$ & $\mathrm{N}$ & $\mathrm{C}$ & $\begin{array}{l}\text { The presence of the } \\
\text { rubber mats on the } \\
\text { steps, checking of } \\
\text { the condition of the } \\
\text { doors by the tech- } \\
\text { nical service of the } \\
\text { hotel }\end{array}$ & Yes & Yes & Yes & - & - & CCP & $\begin{array}{l}\text { Increasing of the } \\
\text { control level of } \\
\text { technical systems } \\
\text { serviceability }\end{array}$ \\
\hline \multirow{2}{*}{ 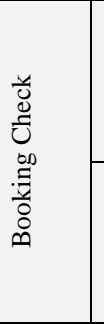 } & Informative & $\begin{array}{l}\text { An error occurred } \\
\text { while grabbing a } \\
\text { staff data at the } \\
\text { booking, } \\
\text { No booking }\end{array}$ & $\mathrm{N}$ & $\mathrm{C}$ & $\begin{array}{l}\text { Verification of data } \\
\text { by the administra- } \\
\text { tor, clarifying them } \\
\text { when making a } \\
\text { reservation }\end{array}$ & Yes & No & - & - & - & $\mathrm{CP}$ & $\begin{array}{l}\text { Monitoring of the } \\
\text { effectiveness of the } \\
\text { IT program and the } \\
\text { rules of working } \\
\text { with them }\end{array}$ \\
\hline & Economical & $\begin{array}{l}\text { An error of book- } \\
\text { ing calculating }\end{array}$ & $\mathrm{N}$ & $\mathrm{C}$ & $\begin{array}{l}\text { Verification of data } \\
\text { by the consumer } \\
\text { and the administra- } \\
\text { tor when making a } \\
\text { reservation }\end{array}$ & Yes & Yes & No & No & - & $\mathrm{CP}$ & $\begin{array}{l}\text { Monitoring the } \\
\text { effectiveness of the } \\
\text { IT program and the } \\
\text { rules of working } \\
\text { with them }\end{array}$ \\
\hline 胥 & Informative & $\begin{array}{l}\text { Error while filling } \\
\text { of data, filling of } \\
\text { data of another } \\
\text { visitor }\end{array}$ & $\mathrm{N}$ & $\mathrm{C}$ & $\begin{array}{l}\text { Strict distribution of } \\
\text { responsibilities } \\
\text { between service } \\
\text { staff }\end{array}$ & Yes & No & - & - & - & $\mathrm{CP}$ & $\begin{array}{l}\text { Monitoring the } \\
\text { work of the staff } \\
\text { service }\end{array}$ \\
\hline \multirow{2}{*}{ 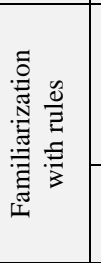 } & Biological & $\begin{array}{l}\text { Delivery of } \mathrm{m} / \mathrm{o} \\
\text { from the staff } \\
\text { during the personal } \\
\text { contact. Dirty } \\
\text { equipment }\end{array}$ & $\mathrm{N}$ & $\bar{C}$ & $\begin{array}{l}\text { Checking of the } \\
\text { health by the for- } \\
\text { mal inspections }\end{array}$ & Yes & Yes & Yes & - & - & CCP & $\begin{array}{l}\text { Monitoring of the } \\
\text { staff health, identi- } \\
\text { fying symptoms at } \\
\text { the early stages }\end{array}$ \\
\hline & Physical & $\begin{array}{l}\text { Problems with } \\
\text { equipment, furni- } \\
\text { ture }\end{array}$ & $\mathrm{N}$ & $\mathrm{N}$ & $\begin{array}{l}\text { Inspection of } \\
\text { equipment by } \\
\text { technical service }\end{array}$ & Yes & Yes & No & - & - & $\mathrm{CP}$ & $\begin{array}{l}\text { Monitoring of the } \\
\text { technical service } \\
\text { effectiveness }\end{array}$ \\
\hline 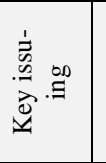 & Qualitative & $\begin{array}{l}\text { Incorrect encoding } \\
\text { due to the failure } \\
\text { of the IT service }\end{array}$ & $\mathrm{N}$ & $\mathrm{N}$ & $\begin{array}{l}\text { Checking of the IT } \\
\text { Service work }\end{array}$ & Yes & Yes & No & No & - & $\mathrm{CP}$ & $\begin{array}{l}\text { Monitoring of the } \\
\text { IT program effec- } \\
\text { tiveness and the } \\
\text { rules of working } \\
\text { with them }\end{array}$ \\
\hline \multirow{2}{*}{ 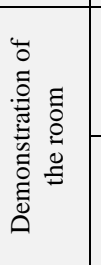 } & Biological & $\begin{array}{l}\text { Delivery of } \mathrm{m} / \mathrm{o} \\
\text { from the staff } \\
\text { during the personal } \\
\text { contact }\end{array}$ & $\mathrm{N}$ & $\mathrm{C}$ & $\begin{array}{l}\text { Checking of the } \\
\text { health by the for- } \\
\text { mal inspections }\end{array}$ & Yes & Yes & Yes & - & - & CCP & $\begin{array}{l}\text { Monitoring of the } \\
\text { staff health, identify- } \\
\text { ing symptoms at the } \\
\text { early stages }\end{array}$ \\
\hline & Qualitative & $\begin{array}{l}\text { Equipment failure } \\
\text { in the room }\end{array}$ & $\mathrm{N}$ & $\mathrm{N}$ & $\begin{array}{l}\text { Checking of the } \\
\text { room condition by } \\
\text { the technical ser- } \\
\text { vice }\end{array}$ & Yes & Yes & No & No & - & $\mathrm{CP}$ & $\begin{array}{l}\text { Monitoring of the } \\
\text { technical service } \\
\text { effectiveness }\end{array}$ \\
\hline 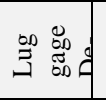 & Physical & $\begin{array}{l}\text { Dispensing of a } \\
\text { stranger luggage }\end{array}$ & $\mathrm{N}$ & $\mathrm{N}$ & $\begin{array}{l}\text { Marking of lug- } \\
\text { gage when taken to } \\
\text { the hotel }\end{array}$ & Yes & Yes & No & No & - & $\mathrm{CP}$ & $\begin{array}{l}\text { Additional instruc- } \\
\text { tion for service } \\
\text { employees }\end{array}$ \\
\hline
\end{tabular}

4 Advantages of the HACCP System Implementing in the Hotel and Catering Business
The results of the study allowed to reveal the main advantages offered by the hotel and catering industry to the development and implementation of the HACCP system in Ukraine:

- control of the products safety and services throughout the life cycle; 
- greater consumer confidence in the safety of products and services;

- rational management of hazardous factors that arise in the production of products and services;

- transition from corrective actions to preventive measures to ensure the quality of products and services;

- solving the security problem based on a unified approach;

- creation of conditions for participation in European and international trade;
- the existence of documented evidence of process control;

- prevention of negative situations in the field of product safety and services, which may negatively affect the reputation and activity of the hotel and catering business;

- the ability to the changes which were caused by the use of advanced equipment, processing procedures, technology advancements.

The advantages of implementing the HACCP system in the hotel and catering facilities are shown in the figure.

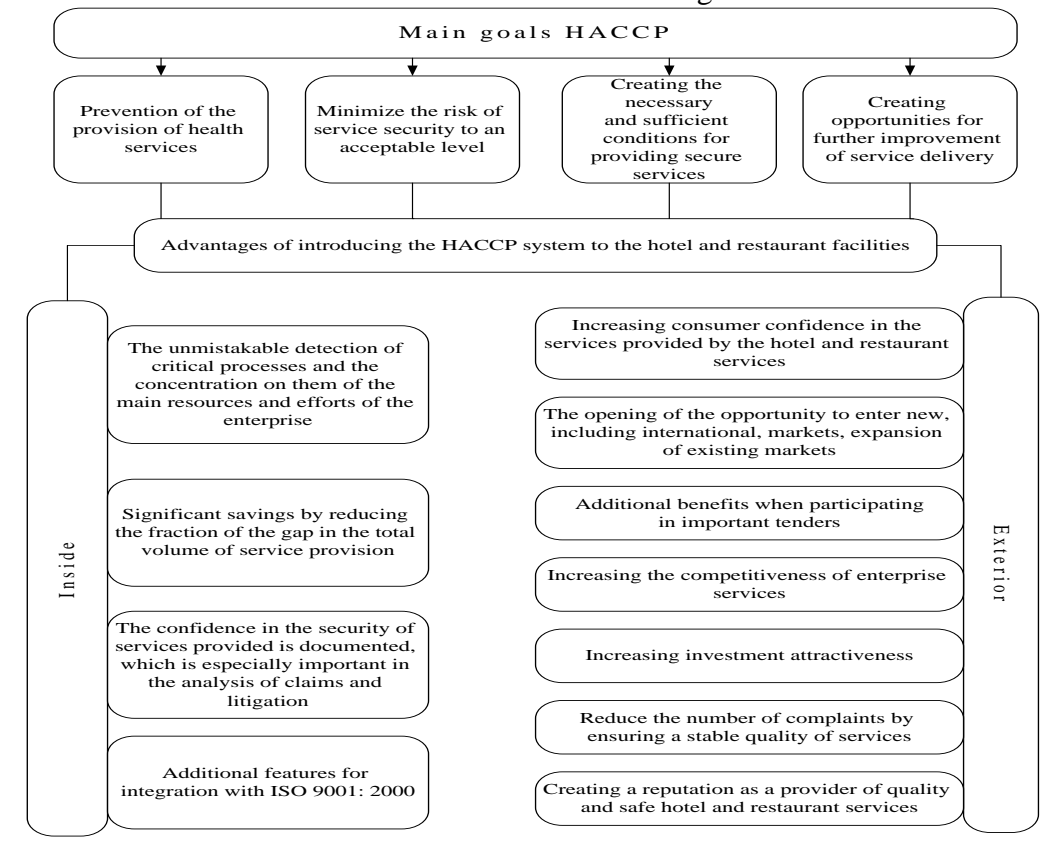

Fig. 1: The advantages of implementing the HACCP system in the hotel and catering facilities.

\section{Conclusion}

The HACCP system is gaining in popularity. It is the main system for ensuring of the food safety. In accordance, HACCP will play an ever-increasing role in ensuring of the food safety, not only as a system that is selected by individual countries but also at a global level.

The main difference of the HACCP system from the previous systems is that the last one was based mainly on periodic research of the source resources and finished products, and according to HACCP, all raw materials and products must be controlled in all stages of production.

The introduction of such a system at the hotel and catering enterprises will allow us to determine how effectively it controls the provision of services and to assess its level in ensuring of the services security in accordance with established standards.

The basic principles of the HACCP system are not completely new, but their acceptance indicates a shift in emphasis from checking the services provided to pre-emptive control of critical moments.

Consequently, the development and implementation of the hotel and catering enterprises of the HACCP system will provide reliable safety of services for consumers, increase economic efficiency by reducing costs and the number of claims, and compliance with international standards will significantly increase the number of tourists.

\section{References}

[1] FAO/WHO (1983) The Role of Food Safety in Health and Development, Report of a Joint FAO/WHO Expert Committee on Food Safety, Technical Report Series 705 WHO.

[2] CAC (1997) Hazard Analysis and Critical Control Point System and Guidelines for its Application, Alinorm 97/13 A, Codex Alimentarius Commission, Rome.

[3] FAO (1998) Food Quality and Safety Systems: A Training Manual on Food Hygiene and the Hazard Analysis and Critical Control Point System, Food and Agriculture Organization of the United National Rome.

[4] Pro bezpeku ta yakist' xarchovy`x produktiv: Zakon Ukrayiny // Golos Ukrayiny. 1997. № 771/97-VR. 23 grudnya - p. 10.

[5] DSTU 41612003 «Sy`stemy` upravlinnya bezpechnistyu xarchovy`x produktiv. Vy`mogy`» 